\title{
Pre- and Post-treatment Effects of Thiourea after Gamma-Irradiation on Dormant Seeds of Solanum surattense Burm. $f$.
}

\author{
Girish Kumar and S. K. Roy \\ Department of Botany, Banaras Hindu University, Varanasi-221005, India
}

Accepted February 23, 1990

Previous studies have shown that thiourea treatment before irradiation offers protection against radiation induced lesions at cellular levels (Mikaelsen 1955, Shozi 1977, Agrawal and Sarma 1981). Reddy (1970) reported that thiourea treatment before irradiation reduced the frequency of chromosome fragments and bridges in dividing root cells of Allium cepa. Thus protection of cellular damage by radiation hazards increased the survival of cells. Radioprotective property of thiourea is due to its sulphur content, which after irradiation works as a sulphydryl compounds (Dale and Davies 1957, Kopp and Charlesby 1963). Sulphydryl or sulphur containing compounds reduce the formation of free radicals induced by X-ray or $\gamma$-ray after radiolysis of water or by forming of some repairing chemicals (Bacq and Alexander 1961, Kopp and Charlesby 1963, Rosin and Stich 1978). Further, such chemicals have gained antimutagenic properties (Gebhart 1974). The protectivity can be explained on the basis of hydrogen donation model in which it is assumed that target radicals are repaired by hydrogen transfer from the sulphydryl group of the protector to the taget radicals (Howard-Flanders 1960, Hutchinson 1961). Kopp and Charlesby (1963) have described that the great ability of thiourea to protect at very low concentrations is ascribed to thiol-thione eqilibrium in solution, which allows a chain reaction form of protection. Thus the protection can be obtained by thiourea treatment prior to irradiation in plant and animal cells (Reddy 1970, Shinoda et al. 1974). Such protective ability of thiourea to gamma-irradiation on dormant seeds is rarely studied. Indeed the protective ability of thiourea on incorporation of ${ }^{3} \mathrm{H}$-thymidine against irradiated seedlings of Solanum is not known. Therefore, the present investigation was designed on dormant seeds of $S$. surattense to note the extent of cytogenetic damages rendered by irradiation at $\mathrm{LD}_{50}$ and $\mathrm{LD}_{90}$ doses and their protection by thiourea.

\section{Materials and methods}

Dry and healthy seeds of Solanum surattense were soaked in distilled water for $24 \mathrm{~h}$ and thereafter treated with or without thiourea $\left(10^{-4}\right.$ to $10^{-1} \mathrm{M}$ concentration, $\left.6 \mathrm{hr}\right)$ in distilled water and exposed to 400 and $600 \mathrm{~Gy}\left(\mathrm{LD}_{50}\right.$ and $\mathrm{LD}_{90}$ dose) of ${ }^{\circ 0} \mathrm{Co}$-gamma rays at 1.584 C. $\mathrm{kg}^{-1} / \mathrm{min}$ at National Botanical Research Institute, Lucknow. At the exposure time moisture content of seeds was $10.8 \%$. Thiourea post-treatment was made on irradiated seeds only, not treated with thiourea previously, at same concentrations and time period. At these concentrations thiourea had no effect on non-irradiated seeds. Following pre- and post-treatment, they were washed with tap water and together with irradiated seeds grown on sand-bed or moist filter paper in growth chamber at $24 \pm 1^{\circ} \mathrm{C}$ with natural day length and light intensity.

For cytological observations root-tips of germling were fixed in Carnoy's solution (acetic acid: alcohol, $1: 3$ ) for $24 \mathrm{hr}$ and squashed in $1 \%$ aceto-orcein. Seedling growth was measured on 2 week old seedlings in respect of irradiated seeds only on dry weight basis and survival of the plants noted thrice a week until no further death was attributed to irradiation. 
In order to study the DNA synthesis rate in gamma-irradiated seeds and in those under pre- and post-treatment with thiourea, seedlings were treated with $3.7 \times 10^{4} \mathrm{~Bq} / \mathrm{ml}{ }^{3} \mathrm{H}$-thymidine (sp. act. $9.62 \times 10^{11} \mathrm{~Bq} / \mathrm{mM}, \mathrm{BARC}$, Bombay) for $48 \mathrm{hr}$ (about 2 cell generations) prior to harvesting. After removal of the medium contaminated with radioactivity, seedlings were washed with cold water and 50 root-tips $(3 \mathrm{~mm}$ long, growing apex, $250 \mathrm{mg}$ ) from each lot decapiteted and homogenised in $3 \mathrm{ml}$ of SSC bufier $(0.15 \mathrm{M}$ sodium chloride, $0.015 \mathrm{M}$ sodium citrate, $\mathrm{pH} \mathrm{7.0)}$ at $4^{\circ} \mathrm{C}$ and incubated at $37^{\circ} \mathrm{C}$ for $50 \mathrm{~min}$ and centrifuged at low speed (2000 $\mathrm{rpm}$ ) for $30 \mathrm{~min}$ at $4{ }^{\circ} \mathrm{C}$. The supernatants were discarded and residue washed with $5 \% \mathrm{PCA}$, finally rinsed in 70-95-100\% alcohol and dried as described by Schlag and Lücke-Huhle (1981). The dried materials transferred to scintillation vials containing $10 \mathrm{ml}$ of toluene phosphor and radioactivity counted in liquid scintillation counter (Beckman LS-7000) after pre-cooling to $+2^{\circ} \mathrm{C}$ as described by Fuchs and de Vries (1972).

\section{Results}

\section{Germination, growth and survival of seedlings}

Seeds treated with thiourea before or after irradiation showed earlier germination than simply irradiated seeds (Table 1). This indicate stimulation of germination by thiourea

Table 1. Pre- and post-treatment effects of thiourea and gamma-irradiation on dormant seeds of $S$. surattense

\begin{tabular}{|c|c|c|c|c|}
\hline \multirow[b]{2}{*}{ Treatment } & \multicolumn{2}{|c|}{ Exposure at $\mathrm{LD}_{50}(400 \mathrm{~Gy})$} & \multicolumn{2}{|c|}{ Exposure at $\mathrm{LD}_{90}(600 \mathrm{~Gy})$} \\
\hline & $\begin{array}{c}\text { Days of } \\
\text { germination } \\
(\text { Mean } \pm \text { SD) }\end{array}$ & $\begin{array}{c}\text { Percentage of } \\
\text { germination } \\
(\text { Mean } \pm \text { SD) }\end{array}$ & $\begin{array}{c}\text { Days of } \\
\text { germination } \\
\text { (Mean } \pm \text { SD) }\end{array}$ & $\begin{array}{l}\text { Percentage of } \\
\text { germination } \\
\text { (Mean } \pm \text { SD) }\end{array}$ \\
\hline Water & $20.85 \pm 3.38$ & $93.50 \pm 2.15$ & $30.00 \pm 3.58$ & $90.81 \pm 2.36$ \\
\hline \multicolumn{5}{|c|}{ Thiourea pre-treatment } \\
\hline $10^{-4} \mathrm{M}$ & $18.36 \pm 2.58$ & $95.40 \pm 2.71$ & $22.66 \pm 2.45$ & $93.58 \pm 2.54$ \\
\hline $10^{-3} \mathrm{M}$ & $15.66 \pm 2.37$ & $94.50 \pm 2.41$ & $18.67 \pm 2.33$ & $95.01 \pm 2.42$ \\
\hline $10^{-2} \mathrm{M}$ & $12.33 \pm 2.30$ & $96.10 \pm 2.17$ & $15.50 \pm 2.10$ & $96.12 \pm 2.59$ \\
\hline $10^{-1} \mathrm{M}$ & $12.21 \pm 2.28$ & $95.78 \pm 2.30$ & $14.52 \pm 2.38$ & $95.68 \pm 2.38$ \\
\hline \multicolumn{5}{|c|}{ Thiourea post-treatment } \\
\hline $10^{-4} \mathrm{M}$ & $20.33 \pm 2.48$ & $94.71 \pm 2.65$ & $25.61 \pm 2.43$ & $93.08 \pm 2.53$ \\
\hline $10^{-3} \mathrm{M}$ & $18.40 \pm 2.61$ & $92.46 \pm 3.12$ & $23.33 \pm 2.58$ & $92.87 \pm 2.62$ \\
\hline $10^{-2} \mathrm{M}$ & $15.50 \pm 2.78$ & $95.28 \pm 2.57$ & $19.48 \pm 2.76$ & \\
\hline $10^{-1} \mathrm{M}$ & $14.00 \pm 2.53$ & $91.85 \pm 2.65$ & $18.20 \pm 2.33$ & $92.50 \pm 2.72$ \\
\hline
\end{tabular}

treatment. But per cent seed germination remained similar in all cases which suggested irradiation alone or in combination with thiourea did not prevent germination. Seedling growth was affected by thiourea pre- and post-treatment after irradiation. Better growth performance than those of other treatments was observed in pre-treated seeds (Fig. 1). Maximum growth was noticed in $10^{-2} \mathrm{M}$ thiourea pretreated seeds where it was about 3 fold greater in respect of irradiated ones. The results suggest that improvement of growth by thiourea treatment showed itself upto certain concentrations beyond which it caused growth inhibition (Fig. 1). The effect of post-treatment nevertheless impaired growth further. It is now clear that thiourea pre-treatment reduced radiation injuries and thereby had cutdown lethal effects of radiation. Pre-treatment by $10^{-2} \mathrm{M}$ of the chemical recorded 82.13 and $85.20 \%$ seedling survival at sublethal doses of $\mathrm{LD}_{50}$ and $\mathrm{LD}_{00}$, respectively, while post-treatment offered no protection. Indeed, the latter enhanced lethality variously (Fig. 2). 


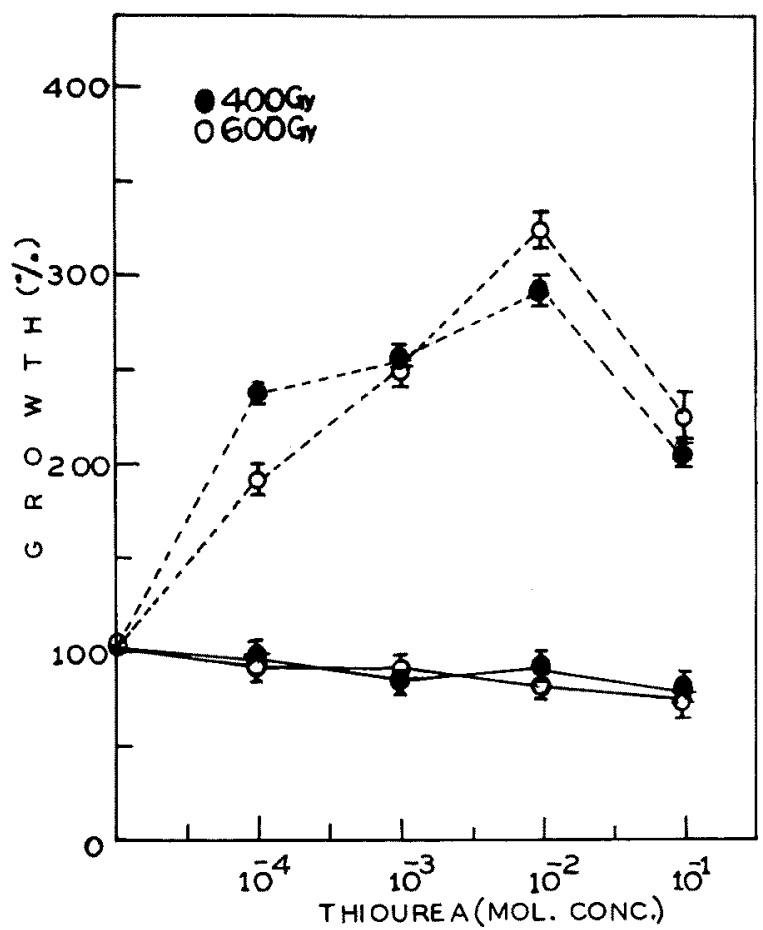

Fig. 1. Growth performance of 15 day old seedlings after pre-(broken lines) and post-treatment (continuous lines) by thiourea on gamma-irradiated seeds of $S$. surattense at $L^{2} D_{50}$ and $L D_{90}$.

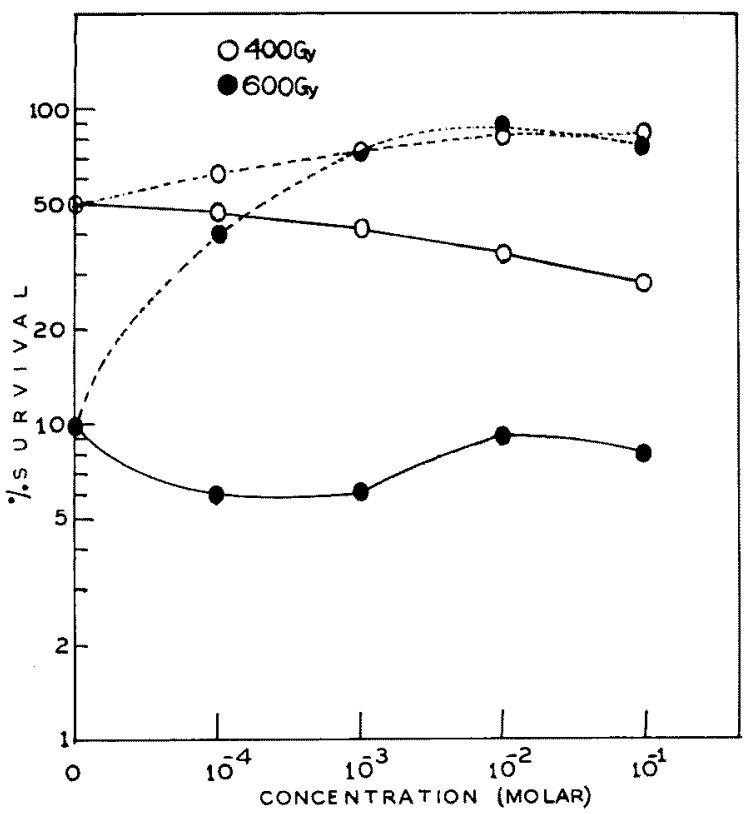

Fig. 2. Seedling survival under pre-(broken lines) and post-treatment (continuous lines) with thiourea against gamma-irradiated seeds of $S$. surattense at $\mathrm{LD}_{50}$ and $L D_{00}$. 


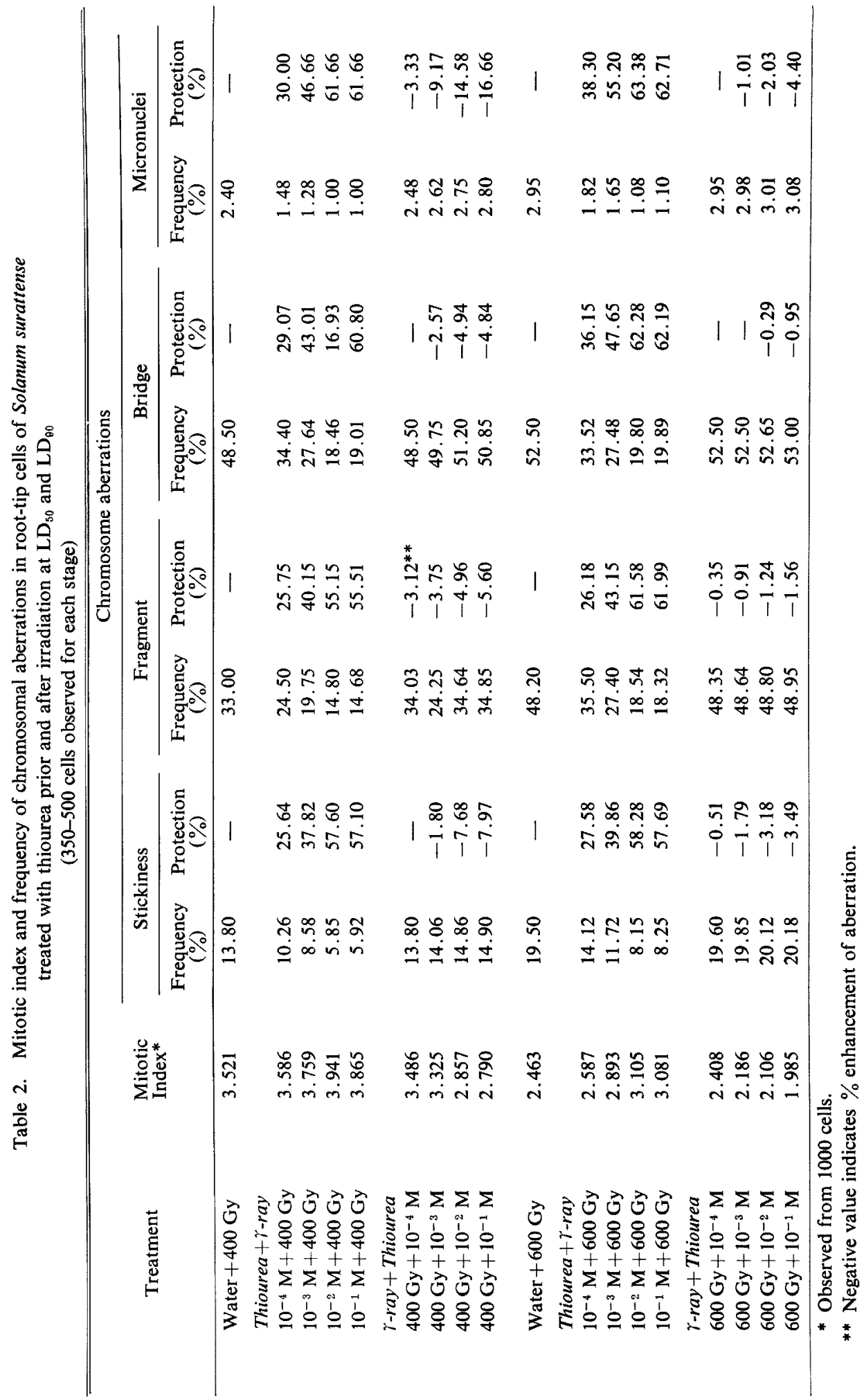




\section{Chromosome aberrations and mitotic index}

Chromosomal abnormalities in gamma-irradiated seeds at 400 and $600 \mathrm{~Gy}$ and those in combination with thiourea pre- and post-treatment are given in Table 2. Pre-treated seeds showed lower percentage of chromosome aberrations than those irradiated alone or posttreated. Maximum protection was offered by $10^{-2} \mathrm{M}$ thiourea at both of sublethal doses of irradiation when these were $57.60,55.15$ and $61.93 \%$ at $\mathrm{LD}_{50}$ and $56.28,61.58$ and $61.93 \%$ at $\mathrm{LD}_{90}$ : the chromosome aberrations being stickness, fragments and bridges, in this order. These also reduced 61.67 and $63.40 \%$ formation of micronuclei without significant alteration in the degree of readioprotection at the two sublethal doses. In other words, radioprotection against a given concentration follows the same pattern irrespective of the dose of irradiation. However, higer concentrations (above the $10^{-2} \mathrm{M}$ ) of thiourea decrease its capability of protection of chromosome aberrations (Table 2). Thiourea post-treatment shows greater chromosome abnormalities than simple irradiation (Table 2). This may point to mutagenic property of thiourea after post-treatment. Besides, rate of cell division is also affected by thiourea treatment with irradiation. Motitic index in treated seeds before irradiation was highest of all treatments employed. The observations indicated that radiation not only induced chromosome aberrations but also prevented cell division and thiourea pre-treatment reduced these effects.

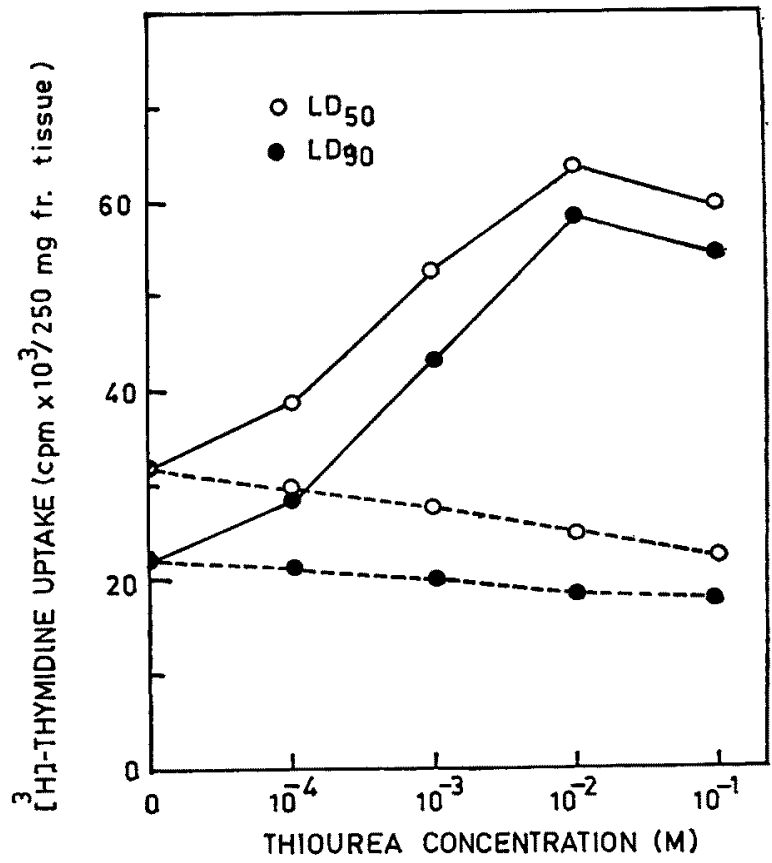

Fig. 3. Variations in $\left({ }^{3} \mathrm{H}\right)$-thymidine uptake by roots of $S$. surattense after pre-(continuous lines) and post-treatment (broken lines) by thiourea against gamma-irradiated seeds at $\mathbf{L D}_{30}$ and $\mathbf{L D}_{90}$.

\section{Radioactivity}

Incorporation of ${ }^{8} \mathrm{H}$-thymidine into labelled DNA fractions in gamma-irradiated, pretreated and post-treated seedlings with thiourea showed that it was greatest in pre-treated seedlings followed by irradiated and post-treated ones (Fig. 3). The results also indicated that maximum uptake was with $10^{-2} \mathrm{M}$ conc. when growth and survival of seedling were greatest. Thus $10^{-2} \mathrm{M}$ thiourea proved most effective concentration for bringing down radia- 
tion hazards. Post-treatment proved unprotective, nevertheless mutagenic.

\section{Discussion}

The present observations have revealed that thiourea treatment before irradiation offers portection against radiation induced lesions at sublethal doses $\left(\mathrm{LD}_{50}\right.$ and $\left.\mathrm{LD}_{90}\right)$. It enhanced seedling survival and improved growth performance. Besides, it reduced radiation induced chromosome aberrations at significant levels $(P<0.05)$. Such protective effect of thiourea was not found under post-treatment. It is limited to certain extent of concentration beyond which the capacity reduces. Protective property of thiourea at lower concentrations against radiation lesions have been scored by previous workers (Bacq and Alexander 1961, Reddy 1970, Agrawal and Sarma 1981). Reddy (1970) obtained $45 \%$ protection of bridges and $33 \%$ of fragments at comparable concentrations of thiourea against $\mathrm{X}$-ray on onion cells and Mikaelsen (1955) secured $48 \%$ of induced chromosome fragments in Tradescantia paludosa with $10^{-3} \mathrm{M}$ thiourea. Further, better seedling survival and growth of plants under post-treatment could be due to disturbed physico-chemical processes and/or greater chromosome aberrations leading to mitotic arrest or necrosis at growing points. May be the mitotic index dropped significantly due to chromosome aberrations or toxic effect generated. Shinoda et al. (1974) have reported that thiourea have radioprotective property with low toxicity. Generally, toxicity tolerant system of Solanum surattense withstand weak solution of thiourea without effect. Irradiation ionizes thiourea molecules by splitting out sulphur which reacts with free radicals formed after radiolysis of water (Dale and Davies 1957, Kopp and Charlesby 1963). In this way it prevents formation of peroxyl or superhydroxyl radicals that cause genetic damage (Feldberg and Garew 1981). Such reactions cannot take place under post-treatment condition when the damage had already been inflicted. Instead, the toxic effect of thiourea then enhances the damaged lesions. This is proven by the present observations which additionally point to impaired DNA replication. Labelled DNA decreased with increasing concentrations of thiourea in post-treatment and at $10^{-1} \mathrm{M}$ it reduced $31.68 \%$ labelled DNA count in respect of $\mathrm{LD}_{90}$ dose of gamma-irradiation. The concomitant drop of mitotic index indicates poor cell division. Incorporation into the DNA fraction of ${ }^{3} \mathrm{H}$-thymidine gradually increased with concetration of thiourea after pre-treatment so that at $10^{-2} \mathrm{M}$ it was about 2 times greater than in seedlings irradiated with gamma-rays alone. Mitotic index was higher in such cases due to rapid cell division in pre-treated cells. Van't Hof and Sparrow (1963) and Van't Hof and Kovacs (1970) have also reported mitotic arrest by irradiation in root cells of Pisum sativum and protection by thiol compounds (Kawasaki 1977). Lessening of labelled DNA incorporation under $\gamma$-irradiation or post-treatment follows inhibition or delay in DNA synthesis probably due to induced single and double strand breaks (Mc Graph and Williams 1966, Schans 1978). Radioprotectors offer protection by diverting the primary energy which affects the breakage of nucleotides (van Hemmen et al. 1974, Lafleur et al. 1980). The degree of damage caused by irradiation or post-treatment decides whether division processes will slow down or stop altogether whereafter development would not be possible. This will lead to ultimate death of the seedlings.

\section{Summary}

Seeds of the medicinal plant Solanum surattense were irradiated with 400 and 600 Gy of gamma-irradiation alone and in combination with thiourea before (pre-treatment) and after (post-treatment) irradiation. It was observed that pre-treatment gave protection against cellular damage induced by irradiation and thereby enhanced seedling survival and growth performance, while post-treatment proved to be mutagenic by increasing seedling death, impaired 
growth and frequency of chromosome aberrations. Mitotic index was significantly poor in post-treated seedlings.

Incorporation of ${ }^{3} \mathrm{H}$-thymidine into DNA fraction gradually increased with pre-treatments and reversed in post-treatment. Besides offering radioprotection pre-treatment improved cell division and DNA synthesis rate.

\section{Acknowledgements}

Authors are thankful to Council of Science and Technology, Uttar Pradesh, Lucknow for financial assistance and Director, National Botanical Research Institute, Lucknow for seed irradiation.

\section{References}

Agrawal, S. B. and Sarma, Y. S. R. K. 1981. The influence of pretreatment of thiourea with gamma rays on the chromosomal aberrations in two green algae, Rhizoclonium heroglyphicum (Ae) Kuetz and Oedogonium gunnii Wittr. J. Cytol. Genet. 16: 65-69.

Bacq, Z. M. and Alexander, P. 1961. Fundamentals of Radiobiology. Pergamon Press, Oxford, p. 111.

Dale, W. M. and Davies, J. V. 1957 . Radiation effects on aqueous thiourea solution. Radiat. Res. 7: 35-46.

Feldberg, R. and Garew, A. J. 1981. Water radiolysis products nucleotide damage in gamma-irradiated DNA. Int. J. Radiat. Biol. 40: 11-17.

Fuchs, A. and De Vries, F. W. 1972. A comparison of methods for the preparation of ${ }^{14} \mathrm{C}$-labelled plant tissue for liquid scintillation counting. Int. J. Appl. Radiat. Isotop 23: 361-369.

Gebhart, E. 1974. Antimutagens. Humangenetik 24: 1-32.

Howard-Flanders, P. 1960 . Effect of oxygen on the radiosensitivity of bacteriophage in the presence of sulphydryl compounds. Nature (London) 186: 485-487.

Hutchinson, F. 1961. Modifying factors in the inactivation of biological macromolecules. Radiat. Res. 2 (Suppl.): 49-64.

Kawasaki, S. 1977. Protective effect of various thiol compounds on radiation-induced mitotic delay in cultured mammalian cells (L-5). Int. J. Radiat. Biol. 32: 577-581.

Kopp, P. M. and Charlesby, A. 1963. Radiation protection of aqueous polyvinylpyrrolidone solution by thiourea. Int. J. Radiat. Biol. 7 : 173-196.

Lafleur, M. V. M., Woldhuis, J. and Loman, H. 1980. Effects of sulphydryl compounds on the radiation damage in biologically active DNA. Int. J. Radiat. Biol. 37: 493-498.

Mc Graph, R. A. and Williams, R. W. 1966. Reconstruction in vivo of irradiated E. coli DNA, the rejoining of broken pieces. Nature (Lond.) 212: 534-535.

Mikaelsen, K. 1955. The protective property of thiourea against radiation induced chromosome aberration. Exp. Cell Res. 8: 400-403.

Reddy, S. B. 1970. A study on the radioprotection properties of thiourea against radiation induced chromosome damage. Can. J. Cytol. \& Genet. 12: 685-688.

Rosin, M. P. and Stich, H. F. 1978. Inhibitory effect of reducing agent on N-acetoxy- and N-hydroxy-2 acetylaminofluorene-induced mutagenesis. Cancer Res. 38: 1307-1310.

Schans, G. P. Van der. 1978. Gamma-ray induced double-strand breaks in DNA resulting from randomlyinflicted single-strand break: Temporal local denaturation, a new radiation phenomenon? Int. J. Radiat. Biol. 33: 105-120.

Schlag, H. and Lücke-Huhle, C. 1981. The influence of ionization density on the DNA synthetic phase and survival of irradiated mammalian cells. Int. J. Radiat. Biol. 38: 75-89.

Shinoda, M., Ohta, S., Takagi, Y. and Akaboshi, S. 1974. Studies on chemical protectors against radiation. XIV. Radiation protective activities of sulfur containing compounds against X-irradiation. Yakugaku Zasshi 94: 1419-1424.

van Hemmen, J. J., Meulling, W. J. A., de Jong, J. and Luthjens, L. H. 1974. Radioprotection of biologically active DNA by cysteamine. A rapid-mix study. Int. J. Radiat. Biol. 25: 455-464.

Van't Hof, J. and Kovacs, C. J. 1970 . Mitotic delay in two biochemically different $G_{1}$ cell population in cultured root of pea (Pisum sativum). Radiat. Res. 44: 700-712.

- and Sparrow, A. H. 1963. Growth inhibition, mitotic cyle time and cell number in chronically irradiated root meristems of Pisum. Radiation Botany 3: 239-247. 